\title{
KEEFEKTIFAN JUS BUAH BIT DAN LEMON DALAM KENAIKAN KADAR HB PADA IBU HAMIL
}

\author{
Suci Setyiyaningsih ${ }^{1}$, Widayati ${ }^{2}$, Wahyu Kritiningrum ${ }^{3}$ \\ 1Program Studi S1 Kebidanan Fakultas IImu Kesehatan Universitas Ngudi Waluyo \\ Email : Sucisetya04@gmail.com \\ 2Dosen S1 Kebidanan Fakultas IImu Kesehatan Universitas Ngudi Waluyo \\ Email : widayati.alif@gmail.com \\ ${ }^{3}$ Dosen S1 Kebidanan Fakultas IImu Kesehatan Universitas Ngudi Waluyo \\ Email : kristiningrumwahyu@gmail.com
}

\begin{abstract}
Background :Lack of iron in food is a common cause of anemia experienced by pregnant women. Iron requirements increase during pregnancy, especially in the last trimester.Beet juice (Beta Vulgaris)is a source of non-pharmacological alternative foods containing iron which can increase hemoglobin levels in pregnant women.

Purpose : To find out the effectivity of beet root juice and lemon combination with Fe tablet in increasing $\mathrm{Hb}$ level on pregnant woman with anemia in Wonorejo Village, Pringapus Public Health Service working area.

Method :The study used a pre experiment design with of One group pretest-posttestdesign. The population in this study were all pregnant women with anemia in Wonorejo Village, Pringapus Public Health Service working area. The sampling technique in this study was Total Sampling, namely 14 pregnant women with anemia.Research used primary and secondary data. Bivariate Analysis using t-test, data processing by SPSS 20.0

Results :The study showed hemoglobin levels in pregnant women with anemia before being given beet and lemon fruit juice combination with an average tablet of $10.25 \mathrm{~g} / \mathrm{dl}$, after being given the combinations with an average fe tablet of $11.35 \mathrm{~g} / \mathrm{dl}$,or an average increase of $1.1 \mathrm{~g} / \mathrm{dl}$. T-count value was $-23,939$ with a $p$-value of $0,000<\alpha(0,05)$. There was a significant effectiveness of increasing hemoglobin levels after being given beet and lemon fruit juice combination with tablet fe in pregnant women with anemia in Wonorejo Village, Pringapus Public Health Service working area.

Conclusion :Beet root juice and lemon combination with Fe tablet in increasing hemoglobin level on pregnant woman with anemia.

Suggestion It is hoped that the community will increase understanding of the importance of beets and lemons and pregnant women consume beet juice combined with lemons.
\end{abstract}

Keywords $\quad$ : Anemia, Beet, Pregnant Woman

\section{ABSTRAK}

Latar belakang :Kurangnya zat besi dalam makanan merupakan penyebab umum anemia yang dialami oleh wanita hamil. Kebutuhan zat besi meningkat selama kehamilan, terutama pada trimester terakhir. Jus buah bit (Beta Vulgaris) merupakan salah satu sumber makanan alternatife non farmakologi mengandung zat besi yang dapat meningkatkan kadar hemoglobin pada ibu hamil.

Tujuan: Untuk mengetahui keefektifan kombinasi jus buah bit (Beta Vulgaris I) dan lemon dengan tablet fe dalam kenaikan kadar hb pada ibu hamil dengan anemia di Desa Wonorejo wilayah kerja Puskesmas Pringapus.

Metode :Penelitian menggunakan desain pre experiment dengan rancangan one group pretestposttest.Populasi dalam penelitian ini adalah seluruh ibu hamil dengan anemia di Desa Wonorejo wilayah kerja Puskesmas Pringapus.Teknik pengambilan sampel penelitian menggunakan total sampling yaitu 14 responden ibu hamil dengan anemia.Penelitian menggunakan data primer dan sekunder.Analisis Bivariat menggunakan uji $t$ test (Paired) dengan menggunakan pengolahan data SPSS 20.0

Hasil : Penelitian menunjukkan kadar hemoglobin pada ibu hamil dengan anemia sebelum diberikan kombinasi jus buah bit dan lemon dengan tablet fe rata-rata sebesar 10,25 g/dl, sesudah diberikan kombinasi jus buah bit dan lemon dengan tablet fe rata-rata sebesar $11,35 \mathrm{~g} / \mathrm{dl}$, atau rata-rata meningkat $1,1 \mathrm{~g} / \mathrm{dl}$. Didapatkan nilai $t$ hitung $-23,939$ dengan $p$-value sebesar $0,000<a(0,05)$ yang berarti ada keefektifan secara signifikan 
kenaikan kadar hemoglobin setelah diberikan kombinasi jus buah bit dan lemon dengan tablet fe pada ibu hamil dengan anemia di Desa Wonorejo Wilayah Kerja Puskesmas Pringapus.

Simpulan : Kombinasi jus buah bit dan lemon dengan tablet fe dapat meningkatkan kadar hemoglobin pada ibu hamil dengan anemia.

Saran Diharapkan masyarakat meningkatkan pemahaman tentang pentingnya buah bit dan lemon dan ibu hamil mengkonsumsi jus buah bit yang dikombinasi dengan lemon.

Kata Kunci : Anemia, Bit, Ibu Hamil

\section{PENDAHULUAN}

Kehamilan didefinisikan sebagai fertilisasi atau penyatuan dari spermatozoa dan ovum kemudian dilanjutkan dengan nidasi atau implantasi.Pertumbuhan dan perkembangan janin intra uterine di mulai sejak konsepsi dan berakhir sampai permulaan persalinan (Prawirohardjo, 2010).

Wanita hamil membutuhkan asupan gizi yang cukup untuk dirinya dan bayi yang dikandungnya ibu hamil yang mengalami kekurangan asupan gizi, akan menyebabkan kelainan pada janin yang dikandungnya ibu hamil yang mengalami kelebihan gizi juga tidak baik bagi pertumbuhan bayinya (Istiany, 2013).

Anemia pada kehamilan merupakan masalah nasional karena mencerminkan nilai kesejahteraan sosial ekonomi masyarakat, dan pengaruhnya sangat besar terhadap kualitas sumber daya manusia. Anemia pada ibu hamil disebut juga "potential danger to mother and child", karena itulah anemia pada ibu hamil memerlukan perhatian serius dari semua pihak yang berkaitan dalam pelayanan kesehatan (KemenKes, RI 2016)

Anemia dalam kehamilan adalah suatu kondisi ibu dengan kadar nilai hemoglobin di bawah $11 \mathrm{gr} \%$ pada trimester satu dan tiga, atau kadar nilai hemoglobin kurang dari 10,5 gr\% pada trimester dua (Prawirohardjo, 2010).

Anemia sering terjadi pada saat kehamilan karena darah mengalami hemodelusi (pengenceran) dengan peningkatan volume sel darah merah $30 \%$ sampai $40 \%$ yang puncaknya terjadi pada kehamilan 32 minggu sampai 34 minggu. Prevelensi anemia masih tinggi, dibuktikan dengan data WHO yaitu secara global prevelensi anemia pada ibu hamil di seluruh dunia adalah sebesar 41,8\% (WHO, 2015).

Ibu hamil yang menderita anemia berisiko mengalami keguguran, bayi lahir sebelum waktunya, bayi berat lahir rendah, serta perdarahan sebelum saat dan setelah melahirkan. Dampak terhadap anak yang dilahirkan oleh ibu yang anemia menyebabkan bayi lahir dengan persediaan zat besi yang sangat sedikit didalam tubuhnya sehingga berisiko mengalami anemia pada usia dini, yang dapat mengakibatkan gangguan atau hambatan pertumbuhan dan perkembangan anak (WHO, 2015).

Berdasarkan (Riskesdas) tahun 2013, prevelensi anemia pada ibu hamil di Indonesia sebesar $50,1 \%$ dan Provinsi Jawa Tengah memiliki jumlah ibu hamil dengan anemia sebesar $57,1 \%$ dengan presentase pemberian tablet $\mathrm{Fe}$ terendah kota Brebes pada tahun 2016. Sementara di Kabupaten Semarang dengan presentase pemberian tablet $\mathrm{Fe}$ terendah adalah Kecematan Pringapus yaitu sebanyak 67,5\% (Dinkes Jateng, 2016).

Berdasarkan data Puskesmas Pringapus jumlah ibu hamil yang menderita anemia pada tahun 2016 sebanyak $57,20 \%$ dan pada tahun 2017 terdapat sebanyak $61,42 \%$ ibu hamil yang mengalami anemia. Puskesmas Pringapus mempunyai wilayah binaan desa yaitu desa Klepu, Pringapus, Pringsari, Jatirunggo, Derekan, Wonorejo, Wonoyoso, Candirejo, dan Penawangan. Berdasarkan data dari Puskesmas Pringapus dari bulan Februari-Juni 2018 ibu hamil dengan anemia tertinggi di Desa Wonorejo sebesar 9,13\% dengan jumlah ibu hamil anemia terendah Desa Penawangan sebesar 2,9\%. Desa Wonorejo pada tanggal 2-20 Juli ada 14 ibu hamil dengan anemia dari 39 ibu hamil.

Secara umum tingginya prevelensi anemia disebabkan oleh beberapa faktor diantaranya rendah asupan zat besi dan zat gizi lainnya seperti vitamin A, C, Folat, Riboplafin dan B12 (Prawirohardjo, 2010).

Upaya pencegahan dan penanggulangan anemia pada dasarnya dengan terapi farmakologi yaitu dengan pemberian $60 \mathrm{mg}$ tablet $\mathrm{Fe}$ dan 50 nanogram asam folat selama kehamilan. Ibu hamil harus mengkonsumsi tablet $\mathrm{Fe}$ minimal 1 tablet setiap hari hingga 90 tablet. Selain terapi farmakologi dapat juga diberikan terapi non farmakologi.

Buah bit salah satu terapi non farmakologi yang menawarkan manfaat kesehatan yang besar. Diantara semua buah bit, buah bit adalah salah satu 
buah yang mengandung kadar zat besi yang cukup tinggi dibandingkan dengan buah yang lain yaitu buah naga dan buah melon. Kadar zat besi pada buah bit yaitu 7,4\% (Muzaki, 2017). Zat besi penting untuk pembentukan dan mempertahankan kesehatan sel darah merah sehingga bisa menjamin sirkulasi oksigen dan zat gizi yang dibutuhkan ibu hamil. Buah bit mengandung vitamin $C$ yang sangat baik untuk membantu penyerapan zat besi dan mengatasi masalah anemia (Musbikin, 2008).

Jus adalah minuman ringan yang dibuat dari buah dan air dengan atau tanpa tambahan gula. Jus buah diolah menggunakan blender dengan cara mencampurkan komposisi berupa buah, air, dan penambah lainnya (Muzaki, 2017).

Produksi jus buah pada umumnya mempunyai citra rasa yang khas dan bervariasi, sehingga pada penelitian ini jus buah bit yang dihasilkan diharapkan dapat diolah dengan buah yang bervariasi agar mempunyai citra rasa dan kandungan gizi yang optimal. Jus buah bit akan ditambahkan dengan sari buah jeruk lemon sebagai variasi buah dari jus buah bit, jeruk lemon mengandung asam-asam yang berperan pada pembentukan rasa asam buah. Buah jeruk lemon merupakan salah satu sumber vitamin $\mathrm{C}$ yang tinggi dibandingkan dengan jeruk nipis serta sebagai sumber vitamin A, B1, B2, Fosfor, Kalsium dan Pectin (Muzaki, 2017).

Ibu hamil dianjurkan untuk mengkonsumsi vitamin $C$ karena dapat membantu penyerapan zat besi.Konsumsi vitamin $C$ dapat membantu meningkatkan penyerapan zat besi. Asupan vitamin $C$ rendah dapat memberikan implikasi terhadap kadar hemoglobin ibu hamil. Kadar Hemoglobin dalam darah meningkat maka asupan makanan dan oksigen dalam darah dapat diedarkan ke seluruh jaringan tubuh yang akhirnya dapat mendukung kelangsungan hidup dan pertumbuhan janin (Fatimah, 2011).

\section{METODE PENELITIAN}

Penelitian ini menggunakan metode Pre test dan Post tes One group design. Responden pada penelitian ini yaitu semua ibu hamil dengan anemia di Desa Wonorejo Wilayah Kerja Puskesmas Pringapus. Sampel diambil dengan teknik total sampling dengan sampel 14 responden ibu hamil dengan Anemia di Desa Wonorejo Wilayah Kerja Puskesmas Pringapus. Semua responden dilakukan pemeriksaan kadar $\mathrm{Hb}$ dengan Easy touch $\mathrm{GHb}$, selanjutnya responden diberikan jus buah bit 100 gram dan dikombinasikan dengan jeruk lemon 5 gram dengan tetap mengkonsumsi tablet Fe selama lima hari, setelah lima hari semua responden diperiksa kembali kadar Hemoglobinnya. Analisis hasil dilakukan dengan menggunakan Uji Normalitas menggunakan Shapiro Wilk dan menggunkan Uji Independent $t$ test untuk pengujian keefektifan variabel independen.

\section{HASIL PENELITIAN DAN PEMBAHASAN. Analisa Univariat}

Tabel 1 menunjukkan bahwa dari 14 ibu hamil dengan anemia yang diteliti, sebelum diberikan kombinasi jus buah bit dan lemon dengan tablet fe sebesar 10,25 g/dl dengan standar devisi 0,38180 , kadar hemoglobin paling rendah $9,70 \mathrm{~g} / \mathrm{dl}$ dan paling besar $10,80 \mathrm{~g} / \mathrm{dl}$.

Tabel 1 Deskripsi kadar Hb ibu hamil dengan anemia sebelum diberikan kombinasi jus buah bit dan lemon dengan tablet Fe

\begin{tabular}{lccccc}
\hline Variabel & $\mathrm{N}$ & Mean & $\mathrm{SD}$ & Min & Max \\
\hline Kadar $\mathrm{Hb}(\mathrm{gr} / \mathrm{dl})$ & 14 & 10,25 & 0,38180 & 9,70 & 10,80 \\
\hline
\end{tabular}

Tabel 2 Deskripsi kadar Hb ibu hamil dengan anemia sesudah diberikan kombinasi jus buah bit dan lemon dengan tablet $\mathrm{Fe}$

\begin{tabular}{cccrcc}
\hline Variabel & $\mathrm{N}$ & Mean & $\mathrm{SD}$ & Min & Max \\
\hline Kadar $\mathrm{Hb}(\mathrm{gr} / \mathrm{dl})$ & 14 & 11,35 & 0,38173 & 10,80 & 12,10 \\
\hline
\end{tabular}

Tabel 2 menunjukkan bahwa dari 14 ibu hamil dengan anemia yang diteliti, sesudah diberikan kombinasi jus buah bit dan lemon dengan tablet Fe menjadi sebesar $11,35 \mathrm{~g} / \mathrm{dl}$ dengan standar deviasi 0,38173, kadar hemoglobin paling rendah $10,80 \mathrm{~g} / \mathrm{dl}$ dan paling besar $12,10 \mathrm{~g} / \mathrm{dl}$. 
Analisa Bivariat

Tabel 3 Uji Normalitas

\begin{tabular}{clccl}
\hline Variabel & Perlakuan & $\mathrm{N}$ & P-value & \multicolumn{1}{c}{ Kesimpulan } \\
\hline Kadar Hb (gr/dl) & Pre & 14 & 0,159 & Normal \\
& Post & 14 & 0,823 & Normal \\
\hline
\end{tabular}

Tabel 4 Keefektifan Kombinasi jus Buah Bit dan Lemon dengan Tablet Fe dalam Kenaikan Kadar Hb pada Ibu Hamil dengan Anemia

\begin{tabular}{ccccccc}
\hline Variabel & Perlakuan & $\mathrm{N}$ & Mean & SD & T & P-Value \\
\hline \multirow{2}{*}{ Kadar Hb (gr/dl) $)$} & $\begin{array}{l}\text { Sebelum } \\
\text { Sesudah }\end{array}$ & \multirow{2}{*}{14} & $-1,10714$ & 0,17305 & $-23,939$ & 0,000 \\
\hline
\end{tabular}

Berdasarkan uji $t$ test (Paired), di dapatkan nilai $t$ hitung sebesar $-23,939$ dengan $p$-value sebesar 0,000 . Terlihat bahwa $p$-value $0,000<a$ $(0,05)$, ini menunjukkan bahwa ada perbedaan secara signifikan kadar hemoglobin pada ibu hamil dengan anemia sebelum dan sesudah diberikan kombinasi jus buah bit dan lemon dengan tablet fe di desa Wonorejo wilayah kerja Puskesmas Pringapus. Ini juga menunjukkan bahwa ada keefektifan secara signifikan kombinasi jus buah bit dan lemon dengan tablet fe dalam kenaikan kadar $\mathrm{Hb}$ pada ibu hamil dengan anemia di desa Wonorejo wilayah kerja Puskesmas Pringapus.

\section{PEMBAHASAN}

Gambaran Kadar Hemoglobin Ibu Hamil dengan Anemia Sebelum diberikan Kombinasi Jus Buah Bit (Beta vulgaris $L$ ) dan Lemon dengan Tablet Fe

Berdasarkan penelitian yang telah dilakukan di desa Wonorejo wilayah kerja Puskesmas Pringapus didapatkan hasil rata-rata kadar hemoglobin ibu hamil dengan anemia sebelum diberikan kombinasi jus buah bit dan lemon dengan tablet fe yaitu 10,25 g.dl.

Hemoglobin merupakan protein yang kaya akan zat besi. Hemoglobin memiliki afinitas (daya gabung) terhadap oksigen dan dnegan oksigen itu membentuk oxihemoglobin di dalam sel darah merah. Melalui fungsi ini oksigen dibawa dari paruparu ke jaringan-jaringan (Pearce, 2009).

Gambaran kadar Hb ibu hamil dengan anemia sesudah diberikan kombinasi jus buah bit dan lemon dengan tablet $\mathrm{Fe}$

Berdasarkan penelitian yang telah dilakukan di desa Wonorejo wilayah kerja Puskesmas Pringapus didapatkan hasil rata-rata kadar $\mathrm{Hb}$ ibu hamil dengan anemia sesudah diberikan kombinasi jus buah bit dan lemon dengan tablet Fe yaitu $11,35 \mathrm{~g} / \mathrm{dl}$.
Penatalaksanaan anemia pada ibu hamil biasanya ada 2 cara yang dilakukan yaitu secara farmakologi dan non farmakologi. Cara farmakologis yaitu dengan pemberian $60 \mathrm{mg}$ tablet Fe dan 50 nanogram asam folat selama kehamilan (Dinkes Jateng, 2016). Adapun cara non farmakologis pengobatan anemia dan pencegahannya salah satu diantaranya adalah dengan cara mengkonsumsi buah bit yang kaya antioksidan dan nutrisi, termasuk magnesium, natrium, kalium, zat besi dan vitamin $\mathrm{C}$ dan betaine.

Makanan merupakan salah satu yang mempengaruhi kejadian anemia. Hal ini dikarenakan komponen zat gizi dalam makanan digunakan untuk menyusun terbentuknya hemoglobin diantaranya zat besi dan protein. Pemilihan pola konsumsi makanan seperti jenis makanan, dan frekuensi makanan yang dikonsumsi dapat berpengaruh terhadap nilai kadar $\mathrm{Hb}$ sesorang (Almatsier, 2011). Kandungan buah bit yaitu zat bes, vitamin C, B1. B2, B3, antioksidan, antikarsinogenik dan silica. Asupan zat besi yang tidak mencukupi kebutuhan tubuh akan mengakibatkan terjadinya anemia karena terganggunya pembentukan sel darah merah (proverawati, 2011).

Berdasarkan hasil penelitian bahwa terjadi peningkatan rata-rata kadar hemoglobin ibu hamil dengan anemia sesudah (Post ) diberikan kombinasi jus buah bit dan lemon dengan tablet fe. Hal ini sesuai dengan penelitian yang dilakukan oleh Kenjale, dkk (2011) di Amerika yang menyebutkan bahwa konsumsi buah bit (yang sudah dibuat jus) akan meningkatkan konsentrasi plasma nitrat pada pasien dengan kelainan arteri, dimana pasien ini mengalami kegagalan penambahan suplai darah dan oksigen untuk jaringan selama bekerja sehingga mengakibatkan rasa nyeri saat berjalan. Pasien yang telah mengkonsumsi jus buah bit ini mengalami 
peningkatan plasma setelah tiga jam dan mampu berjalan lebih lama.

Peningkatan kadar hemoglobin pada ibu hamil dengan anemia didukung oleh adanya interaksi yang baik antar peneliti dna responden serta dukungan dari keluarga untuk mengkonsumsi jus setiap malam dan meminum tablet Fe setiap hari

Keefektifan Kombinasi Jus Buah it (Beta Vulgaris $L$ ) dan Lemon dengan Tablet Fe dalam Kenaikan Kadar $\mathrm{Hb}$ pada lbu Hamil dengan Anemia

Berdasarkan penelitian yang telah dilakukan di desa Wonorejo wilayah Kerja Puskesmas Pringapus, dari semua responden dengan total 14 , mengalami peningkatan rata-rata kadar $\mathrm{Hb}$ sebelum sebesr $10,25 \mathrm{~g} / \mathrm{dl}$ kemudian meningkat menjadi rata-rata $11,35 \mathrm{~g} / \mathrm{dl}$ sesudah diberikan kombinasi jus buah bit dan lemon dengan tablet $\mathrm{Fe}$ atau rata-rata meningkat $1,1 \mathrm{~g} / \mathrm{dl}$.

Folat dibutuhkan untuk pembentukan sel darah merah dan sel darah putih dalam sumsum tulang dan untuk pendewasaannya folat berperan sebagai pembawa karbon tunggal dalam pembentukan hem.Makanan sumber asam folat diantaranya hati, daging tanpa lemak, serelia, bijibjian, kacang-kacangan, dan jeruk (Almatsier, 2011). Selain berfungsi untuk mendorong perkembangan janin, zat besi juga penting pembentukan dan mempertahankan sel darah merah, sehingga bisa menjamin sirkulasi oksigen dan zat-zat gizi yang sangat dibutuhkan ibu hamil (Musbikin, 2008).

Vitamin C mereduksi besi feri menjadi fero
dalam usus halus sehingga mudah diabsorbsi.Vitamin C menghambat pembentukan hemosiderin yang sukar dimobilisasi untuk membebaskan besi bila diperlukan.Absorpsi besi dalam bentuk non hem meningkatkan empat kali bila ada vitamin C. vitamin C berperan dalam memindahkan besi dari transferrin di dalam plasma keferitin hati (Almatsier, 2011). Air perasan buah lemon sangat bermanfaat sebagai antibakteri dan sebagai antioksidan. Vitamin C merupakan kandungan utama air buah lemon yang bermanfaat sebagai antioksidan. Kadungan lainya yaitu asam sitrat yang mampu menurunkan $\mathrm{pH}$ sel bakteri sehingga mampu menghambat aktivitas sel bakteri ( Berti, 2015).

Sesuai dengan penelitian Sundari (2014) tentang perbandingan kenaikan kadar $\mathrm{Hb}$ pada ibu hamil yang diberi $\mathrm{Fe}$ dan buah bit terdapat perbedaan setelah diberikan $\mathrm{Fe}$ dan $\mathrm{Fe}+$ buah bit di wilayah Puskesmas Purwokerto.
Kebutuhan zat besi total terus meningkat setelah 25 minggu hingga 36 minggu untuk kebutuhan plasenta dan janin. Kebutuhan zat besi total mendekati akhir trimester II sekitar $3,5 \mathrm{mg} /$ hari dan sekitar $7 \mathrm{mg} /$ hari pada trimester III. Pemberian tablet zat besi pada semua wanita hamil sekitar 60 $\mathrm{mg} /$ hari selama 90 hari. Suplementasi harus diberikan pada trimester II dan III, saat efisiensi absorpsi meningkat dan resiko terjaidnya mual berkurang (Ani, 2013).

Ibu hamil dianjurkan mengkonsumsi vitamin $C$ karena dapat membantu penyerapan zat besi. Penelitian yang dilakukan Berdasarkan uji $t$ test (Paired) didapatkan nilai $t$ hitung sebesar 23,939 dengan diperoleh $p$-value sebesar 0,000 . Terlihat bahwa $p$-value $0,000<a(0,05)$. Hal ini dikatakan terdapat perbedaan yang signifikan kadar hemoglobin ibu hamil dengan anemia sebelum dan sesudah diberikan kombinasi jus buah bit dan lemon dengan tablet Fe di desa Wonorejo wilayah kerja Puskesmas Pringapus. Hal ini juga menunjukkan bahwa ada keefektifan secara signifikan kombinasi jus buah bit dan lemon dengan tablet Fe dalam kenaikan kadar $\mathrm{Hb}$ pada ibu hamil dengan anemia di desa Wonorejo wilayah kerja Puskesmas Pringapus. Sehingga disimpulkan bahwa pemberian kombinasi jus buah bit dan lemon dengan tablet $\mathrm{Fe}$ efektif terhadap kenaikan kadar hemoglobin ibu hamil dengan anemia.

\section{SIMPULAN}

Berdasarkan penelitian yang telah dilakukan dapat disimpulkan bahwa kombinasi jus buah bit dan lemon yang diberikan dengan tablet $\mathrm{Fe}$ sangat efektif untuk meningkatkan kadar $\mathrm{Hb}$ pada ibu hamil di Desa Wonorejo wilayah kerja Puskesmas Pringapus.

\section{SARAN}

Diharapkan masyarakat meningkatkan pemahaman tentang pentingnya buah bit dan lemon dan ibu hamil mengkonsumsi jus buah bit yang dikombinasi dengan lemon.

\section{DAFTAR PUSTAKA}

Almatsier S. (2012). Prinsip Dasar Ilmu Gizi. Jakarta : GramediaPustaka.

Ani, L. (2013). Anemia Defisiensi Besi.Jakarta : ECG.

Berti, P. 2015. Daya Antibakteri Air Perasan Buah Lemon (Citrus medica) terhadap Porphyromonas gingivalis Dominan Periodontitis (In Vitro). UMS. Surakarta.

Dinas Kesehatan Kab. Semarang (2016). Profil Kesehatan Kab Semarang tahun 2016. 
Semarang ; Dinas Kesehatan Kab Semarang.

Dinas Kesehatan Kota Semarang. (2015). Profil Kesehatan Kota Semarang tahun 2015. Semarang ; Dinas Kesehatan Kota Semarang.

Dinas Kesehatan Provinsi Jawa Tengah. (2014). Profil Kesehatan Provinsi Jawa Tengah tahun

2014.www.dinkesjatengprov.go.id.Diakses tanggal 6 Desember 2017 pukul 22.01.

Dinas Kesehatan Provinsi Jawa Tengah. (2016). Profil Kesehatan Provinsi Jawa Tengah tahun

2016.www.dinkesjatengprov.go.id.Diakses tanggal 6 Desember 2017 pukul 22.01.

Fatimah. (2011). Pola Konsumsi dan Kadar Hemoglobin Pada Ibu Hamil di Kabupaten Maros, Sulawesi Selatan.Jurnal Kesehatan Vol.5 Fakultas Kesehatan Masyarakat.Universitas Hasanuddin. Makassar.

Istiany, Ari dan Ruslianti. (2013). Gizi Terapan. PT Remaja Rosdakarya. Bandung.

Kementerian Kesehatan Republik Indonesia. (2016). Profil Kesehatan Indonesia.Jakarta : Depkes RI. Diperoleh tanggal 04 Desember 2017 dari http://www.kemkes.go.id

Kenjale, A.A. et al. (2011). Dietary Nitrate Supplementation Enhances Exercise Performance in Peripheral Arterial
Diseases. J Appl Physiol (serial on line). Diperoleh tanggal 09 Januari 2018 dari http://www.journal.stikeseub.ac.id

Musbikin, I. (2008). Panduan Bagi Ibu Hamil dan Melahirkan.Yogyakarta : Katahari.

Muzzaki. (201)7. Kitab Jus \& Sayur. Yogyakarta : Perpustakaan Nasional

Pearce,

Evelyn.2009.

AnatomidanFisiologiuntukParamedis. Gram edia. Jakarta.

Prawirohardjo, Sarwono. (2010). IImu Kebidanan. Jakarta ; PT Bina Pustaka.

Proverawati. (2011). Anemia dan Anemia Kehamilan. Yogyakarta : Nuha Medika

Riset Kesehatan Dasar. (2013). Badan Penelitian dan Pengembangan Kesehatan Kementrian kesehatan RI.Diakses tanggal 6 Desember 2017 pukul 22.01.

Sundari, A.E \& Happinasari, O. (2014). Perbandingan Kenaikan Kadar Fe Hb pada Ibu Hamil yang diberi Fe dengan Fe Buah Bit.Purwokerto : Akademi Kebidanan YLPP diperoleh tanggal 28 Januari 2018 dari http://www.//journal.stikeseub.ac.id

WHO. (2015). Wordlwide Prevalence of Anemia 2013-2015. WHO global database on Anemia Geneva.World Health Organization, 2015.Diperoleh tanggal 30 Desember 2017 dari http://www.who.int/vmnis/database/anemia/ anemia_data_status_t3/en 